\title{
PLAIN TEXT
}


This page intentionally left blank 


\section{PLAIN TEXT}

\section{THE POETICS OF COMPUTATION}

\section{$>$ DENNIS TENEN}

STANFORD UNIVERSITY PRESS

STANFORD, CALIFORNIA 
Stanford University Press

Stanford, California

(c) 2017 by the Board of Trustees of the Leland Stanford Junior University.

All rights reserved.

No part of this book may be reproduced or transmitted in any form or by any means, electronic or mechanical, including photocopying and recording, or in any information storage or retrieval system without the prior written permission of Stanford University Press. Printed in the United States of America on acid-free, archival-quality paper Library of Congress Cataloging-in-Publication Data

Names: Tenen, Dennis, author.

Title: Plain text : the poetics of computation / Dennis Tenen.

Description: Stanford, California : Stanford University Press, 2017. | Includes bibliographical references and index.

Identifiers: LCCN 2016052467 (print) | LCCN 2016054558 (ebook) | ISBN 9781503601802 (cloth : alk. paper) | ISBN 9781503602281 (pbk. : alk. paper) | ISBN 9781503602342 (electronic)

Subjects: LCSH: Literature and technology. | Digital media--Philosophy. | Electronic publications. | Electronic publishing.

Classification: LCC PN56.T37 T47 2017 (print) | LCC PN56.T37 (ebook) | DDC 809/.93356--dc23

LC record available at https://lccn.loc.gov/2016052467

Designed by Bruce Lundquist

Typeset at Stanford University Press in 8.5/14 Euphemia 
To Bill Todd and Elaine Scarry,

whose influence on my thought grows with time 
This page intentionally left blank 